\title{
What Have We Learned
}

\section{since I989?}

CHARLES S. MAIER

\begin{abstract}
This paper is a frankly subjective effort to return to questions posed about the nature of communist rule and the sudden collapse of communism in the light of the intervening two decades. It asks, first, why feelings of elation about the transformations of 1989 faded relatively quickly, second, why the communist system collapsed so clamorously, and, third, how might we best describe its earlier operation. The paper suggests that there will always be a sense of let-down after intensely hopeful political activity. It endeavours to provide a model of social complexity that communist rule with its Marxist archetypes of social development could not really master. But it also rejects the idea that 'society' under communism can be judged autonomously apart from the regime that sustained and structured it. Efforts to do so will trivialise the degrees of repression and surveillance. Finally the paper proposes that the nature of communist rule in the decades after Stalin must be described in terms of a 'life cycle' metaphor, such as the idea of 'late style' provides for artistic creation. It is fruitless to describe an ideal type of transformative political regime that makes no allowance for change over time. Hence, returning to the first enquiry, the paper argues that efforts to reclaim communal fulfilment will always exist or revive alongside efforts at individual emancipation.
\end{abstract}

What have we learned since I989?' The harsher version of the question might be, what did historians and social scientists get wrong about I989? Two quick answers have circulated since that historical moment. The first alleged error was a failure of democratic faith before the events of I989-9I. That is, social scientists failed to foresee the collapse of the Communist Party regimes in the Soviet Union and

Leverett Saltonstall Professor of History, Minda de Gunzburg Center for European Studies, 27 Kirkland Street, Cambridge, MA 02 I38, USA; csmaier@fas.harvard.edu.

1 My original instruction, as I understood it, was to reconsider the significance of 1989 in the light of subsequent developments, whether in the real world or in the domain of research and scholarship. I have not consistently kept up with the massive scholarship on the GDR and eastern Europe since the publication in 1997 of my account, Dissolution: The Crisis of Communism and the End of East Germany. The following paper is thus not intended as a survey of I989 in European context, nor as a systematic survey of scholarly literature, but as a rethinking of what ended and why, and how we might seek now to understand the transformation. 
eastern Europe. In contrast to many writers, artists and local activists, they did not take account of the economic, political and moral vulnerabilities of the system. The second alleged error sprang from an excess of democratic faith after the communist collapse. That is, many commentators then envisaged that democratisation would become irreversible throughout most of the world sooner or later - the so-called 'end of history'. I will return to those issues, but in this essay I want primarily to address the transformations themselves and not just our failure to predict them or the so-called triumphalism that followed.

Let us stick with the less reproachful question: what have we learned about the transformations of 1989 in the last twenty years? Many journalists at the time and academic commentators in the two decades since have provided illuminating accounts of the complex processes that were unfolding. They have revealed ambiguous developments, false starts and the fragility of progress. But a question still persists: in what way might we have misunderstood I989? In particular, did some of us at least invest the democratisation of communist Europe with a greater epochal significance than it seems to have twenty years later? Did we become intoxicated on history and lose our scholarly cool? Were we personally too involved in the transformations that we followed day to day, perhaps like parents in their children's achievements. Probably it is fairer or more sensible to ask, do we see I989 differently now from the way we saw it then - each as a younger observer, or perhaps in some cases as a participant, almost twenty years ago? I pose the question not primarily to learn about our collective psychological biographies, but to think anew about the events that had such meaning for us.

Events that appear as radical breaks, caesuras, ruptures, revolutions - the punctuations of 'punctuated equilibrium' - leave behind dramatic impressions that call for immediate interpretation as well as explanation. That is, historians feel the urge not only to account for why they occurred, but to contextualise them quickly in a structure of meanings and assign their epochal significance. Certainly there were many efforts to suggest an underlying meaning or overarching metanarrative to the events of I989. For Timothy Garton Ash, reporting from Gdansk and Prague, the events he described as 'refolution' meant also the revival of Central Europe. For Samuel Huntington, they comprised the third wave of democratisation. For many West Germans who found it hard to credit the activism of their 'once and future' countrymen, a mere 'implosion'; for those attuned to political theory, the triumph of civil society; and, of course for Francis Fukuyama the notorious (but also frequently misunderstood) end of history. ${ }^{2}$

Somehow, almost two decades later, it seems more difficult or less urgent to interpret the changes of 1989 in a world-historical conjuncture. Twenty years is not really a long time, yet given the life cycle of adult historians, it can allow for

2 Timothy Garton Ash, The Uses of Adversity: Essays on the Fate of Central Europe (Harmondsworth: Penguin, I999); and Garton Ash, History of the Present: Essays, Sketches and Dispatches from Europe in the 199os (New York: Random House, I999); also Samuel P. Huntington, The Third Wave: Democratisation in the Late twentieth Century (Norman, OK: University of Nebraska Press, I99I); Francis Fukuyama, The End of History and the Last Man (New York: Free Press, I992). 
radically changed subjective impressions and judgements. Certainly it is sufficient to produce a major sense of distancing from events that seemed to exert such a great transformative impact, the process akin to what Roland Barthes calls 'fading' in his Lover's Dictionary, a sense not of disillusion with the former experience or object of love, but disappointment that remembered intensity retreats so rapidly. Now the evaporation of euphoria is hardly unprecedented in world history. The endorphins stimulated by historical renewal tend to lose their impact after a decade, the trajectory from Bastille to Brumaire. Events from I9I7 to I9I9 in central Europe appeared to many as the dawn of a new age, but by the I930s the promise of that new beginning had dissipated. The progress of everyday politics, the fact that old and often opportunistic political administrators could make their way in the new regimes, the fact that descendants of the Communist parties seem so effortlessly to have morphed into 'social democratic' parties that hold power every alternative legislative period all this has tended to take the bloom off the events. 'Bliss was it in that dawn to be alive', but why did bliss become so impossible to sustain? Events that promised a unique emancipation seem to have delivered workaday progress at best and often shabby politics - Charles Péguy's declension from mystique to politique. ${ }^{3}$

It might be objected that such 'fading' is a problem of memory, not history. History is an analytical and evocative procedure designed in part to counteract the continual reprocessing of memory. But the issues hang together. Our emotional stance conditions our analysis. In what follows I want to consider first the general problem of perceived historical 'letdown', and then some of the prevailing analyses of why the system collapsed and what sort of system it was. These are different issues, but considering them together may advance what I shall take up in conclusion, namely how to resume writing the history of these events.

Two words of warning, however - like the small print on drugstore medications. The first is that my discussion is based primarily on the society I know best: the former German Democratic Republic (East Germany). The GDR, of course, was a special component of the Soviet sphere, since despite all denials it always remained potentially a fragment of a German national unit. And the internal patterns of rule in East Germany inherited qualities from earlier German administrative styles, including Prussian and Saxon. Perhaps Czechoslovakia, with the long Bohemian subjugation to imperial Austria, remained the most similar in the unarticulated styles of authority that pervaded its politics. Each state unit of the Soviet empire had, of course, its individual history. In I989 eastern Europe could return to diversity, to borrow Joseph Rothschild's phrase, but even under communist 'wraps', so to speak, much diversity continued: Ottoman traces in south-east Europe and Romania, a mix of intellectual pride and peasant Catholic traditionalism in Poland and so on. What follows, therefore, relies on generalisations that necessarily obscure nuance, or on my own familiarity with the East German case.

\footnotetext{
${ }^{3}$ Cited in his book revealingly entitled Notre Jeunesse (Paris: Cahiers de la Quinzaine, I9I 5), concerned with the decay of Dreyfusard politics.
} 
Just as problematic - to provide my second word of warning - is that what follows was drafted before the extraordinary financial and economic implosion of the last year or so. The crisis that eastern Europe in particular, but perhaps all the industrial economies, now face may well produce harsh political outcomes we cannot foresee; and this essay might then appear as itself a false reading, premised on a comparatively halcyon interlude. As the old Marxist joke had it, the past is very hard to predict.

\section{Let-down?}

Of course, some of the disillusion twenty years after I989 has been unmerited. Historians often chip away at the drama of events, try to wear them down from historical Himalayas to mere Appalachians, in any case must see them in different lights as years pass. Moreover, by most standards the transformations of I $989-90$ have been extraordinarily successful. East-central Europe has been a region of democratic states and - until the contemporary depression - has largely enjoyed robust growth. There has been no politics of revenge or bloodletting. For a region that had known so many political disasters before, the transition to pluralist regimes has been remarkably successful. It is the trajectory within Putin's Russia itself which raises most questions about what has been achieved. The Gorbachev-Yeltsin reforms may have dismantled communism, but the far longer legacy of bureaucratic state-building appears to have remained powerful underneath. Still, there is no final word to history and even long traditions can crumble. Finally, much of the sombreness that we associated with today's global politics derives not at all from events in east-central Europe. It arises from the overshadowing of Western politics by themes of violence and terror that have become so acute since 200 I but have emerged from regions outside Europe. I think it inappropriate to lament the aftermath of 1989 , which for all its falling short of abstract ideals has yet led to a set of far less oppressive institutions and far fairer opportunities for so many citizens.

Nevertheless, it is fruitless to lecture voters or intellectuals or students that they should not experience some degree of disappointment. Two analyses (and probably many others as well), proposed before I 989 and thus without reference to those events, help us think about post-I989 disillusion. One is that formulated by the late Victor Turner, who in numerous writings argued that although our lives usually proceed within stable structures and expectations, periodically we experience episodes of transcendence or ecstasy or mystical communion created through religious rites of passage. For Turner it was obvious wisdom that moments of exstasis - standing outside oneself - could not last. They were by definition brief interludes between longer moments of stability - moments of 'antistructure' punctuating long-term structures, whether political or religious. Turner certainly did not originate this contrast. It can be extracted earlier from one of sociology's founders, Emile Durkheim, who described states of collective 'effervescence', social integration and 'anomie'. ${ }^{4}$ From Turner's

\footnotetext{
4 See Victor W. Turner, The Ritual Process: Structure and Anti-Structure (Ithaca, NY: Cornell University Press, I977).
} 
type of perspective, the exhilaration of 1989 might be viewed as a powerful and intoxicating episode, but like earlier political upheavals had to remain just an episode. In fact, episodes of anti-structure ultimately strengthen or facilitate the continuing structures by renewing commitment or ventilating energies. In that sense Turner described a particular form of ritual and not revolution. Still, Turner persuasively described the psychology of transitional emancipation and the fall back into ordinary life. Moreover, although his own analysis tends to take structure as unchanging, it does not preclude the possibility that the institutions which are renegotiated after an interval of liberation can be themselves transformed and renewed.

Albert Hirschman has provided a second, somewhat related, but distinct, analysis. For Hirschman, an economist who finds the principle of diminishing returns second nature, any political or economic orientation must bring with it disappointment. He cites Kant (via citations from Joseph Frank citing Karamazin): 'Give a man everything he desires and yet at this very moment he will feel that this everything is not everything. ${ }^{5}$ For Hirschman this means that as participants in society we are condemned to a continuing cycle of engagement with public causes and thereafter private satisfactions, each quest yielding disappointment in its turn. This analysis complements his celebrated discussion of 'exit, voice and loyalty', but stipulates cyclical behaviour and does not outline strategic alternatives.

Insofar as both Turner and Hirschman envisaged recurrent and at least partially cyclical process, their insights take us only so far. Although experiences of intense public involvement and subsequent disillusion (or anti-structure and structure) recur in general, each is specific, and for individual participants (or historians) they may occur only once in a generation or even a lifetime. What may be cyclical for the species is experienced as a one-way loss of public energy, a sort of historical entropy. Still, our problems as historians should not arise just from our own personal sense of disappointment or 'fading'. Historians have had to reckon with a lot of disappointing outcomes - the aftermath of the American Civil War in terms of US race relations, or the inability to exclude former Nazis and fascists from post-war politics. No group should understand better than historians that institutions, habits and personal connections usually trump efforts to mete out justice for sleazy or even cruel past behaviour. Whence, then, our sense of dissatisfaction as historians? Although I draw pre-eminently on the history of the GDR, historians of state socialism in general confront particular sorts of explanatory and interpretive problem with respect to I 989 . The effective collapse of communist power or state socialism raised and continues to raise three difficult sorts of issues.

The first set revolves around motivation - not the motivation of the inter-war, wartime and early post-war period that had led many intellectuals or political actors on the left to become communist to begin with and to accept its discipline, but rather the reasons that persuaded their successors in the late I980s to relinquish power

\footnotetext{
5 Albert O. Hirschman, Shifting Involvement: Private Interests and Public Action (Princeton: Princeton University Press, I982), I I (emphasis in original).
} 
with relatively little resistance. Why did authoritarian regimes effectively dissolve themselves without bloodshed?

The question of why and how communist systems could attract adherents and leaders seemed particularly urgent during the early cold war. The answers that were provided focused on how individual conviction became attracted to a disciplined and apparently powerful movement. ${ }^{6}$ Individual biographies were ransacked for the answers. The question why loyalties failed in 1989 focused less on individual convictions or the energy of the movement than on the failings and costs of a system long in power. Addressing this question presupposed a prior inquiry: what new challenges had arisen in the 'objective' world that led to such devastating reassessments of the costs and benefits of maintaining the institutions of state socialism?

A second issue exercised scholars and commentators throughout the I980s and has hung around ever since. What sort of system did communist rule represent? This is an issue of typology and analogy. Historians claim that a concern with typology separates the political scientists and sociologists from their own discipline. In fact, even the most narrative-based account of supposedly singular phenomena cannot advance without typology, analogue searching and comparison. 'What was it like?' remains a fundamental query whose answer often serves as a response to such questions as, 'What was it?' or 'How did it function?' 'What was/is it like?' is an inquiry that helps to rescue us from unanswerable ontological issues and allows us to work with social and historical analysis. But the 'it' usually prompts two divergent approaches. The first is a state- or regime-centred analysis that elevates politics and 'rule' (Herrschaft, with its encompassing notions of authority) to the object of study. The second is a societybased approach that asks how individuals or groups experienced these regimes and were transformed by them - call it the dialectic of Herrschaft and Gesellschaft, which is taken up below.

There is a further difficulty. Comparison and the resort to ideal types or analogues usually prompt atemporal categories. They tend to posit a stable or even unchanging categorisation, which serves us badly. The more fruitful approach, I believe, is to look at inherently temporal analogues: processes of change rather than frozen structures. Ideological systems find it hard to sustain their revolutionary or counter-revolutionary energy - or, conversely, find it advantageous to shed it. This process as such must be incorporated as a component of any ideal type. But if so, was the system at the end still the same as at the beginning? The problem of comparison is not just a question of identity or 'likeness' across different regimes without respect to time, but an issue of 'likeness' within nominally the same regime across time. What historical trajectory leads to widespread disaffiliation?

These dilemmas of comparison naturally raise a third set of issues, those involving moral evaluation. How bad was communist rule? In the case of the GDR the implicit

${ }^{6}$ Czesław Miłosz, The Captive Mind, trans. Jane Zielonko (New York: Knopf, I953); see also such explanations as Jules Monnerot, Sociology and Psychology of Communism, trans. Jane Degras and Richard Rees (Boston, MA: Beacon, I953). Many autobiographies, of course, wrestled with the reasons why communism was so attractive - pre-eminently the collective memoir by Arthur Koestler et al.: Richard Crossman, ed., The God that Failed: Six Studies in Communism (London: Hamilton, I950). 
comparison was with the Third Reich. Was it as repressive as the Nazis, as repressive as old-fashioned despotism, perhaps more repressive but less sanguinary? But how bad was it, too, in the I980s vis-à-vis the I940s or the I950s? This dimension of inquiry has historiographical consequences. History is strewn with converts: Khrushchev made his early career in the province Stalin singled out for particular devastation. János Kádár presided over the post-I956 repression in Hungary, and then over the transition to 'goulash communism'. But such transitions require practical decisions as well. To what degree should participants in the communist systems have been disqualified from participating in the post-communist regimes?

\section{Why was power relinquished?}

When we write about 1989 (and not about the earlier attractions of communism more generally), the question that was and remains so challenging is why power was surrendered so peacefully. Of course, the largely peaceful transition was partially a question of luck and prudence. It would not have taken much for violence to have intervened - a few rocks thrown by demonstrators, panic on the part of young soldiers and thereafter the unintended escalation of force. Indeed, in Dresden, a few days before the major demonstration of October 9 in Leipzig that did take place without violence, there had been serious clashes with police. Moreover, some of the leaders were probably prepared to use coercion or arrests; consider Erich Mielke, head of the ministry for state security. And, indeed, his troops did counter demonstrations in early October with mass arrests up to a certain point, but only to a certain point. And if we argue that Mielke's intentions were delayed and debated by Politburo colleagues or even just met by foot dragging at the local level, we have to explain why colleagues effectively refused to ratify simple violence.

The reason often cited is that the Soviets - who were instrumental in enforcing communist rule at several key post-war junctures, Berlin in June I953, Hungary in I956, Czechoslovakia in I968 - made it clear that the Soviet rulers were no longer going to provide that support. Under Gorbachev, after all, they were no longer going to rely on their potential monopoly of violence in the Baltic or at home. When more die-hard Soviet leaders attempted a coup to reverse Gorbachev's concessions, they had already let too much time elapse to sustain their adventurous intervention. But the point is that in most of the communist states - China and Romania excepted - the leadership was unwilling to shut down the process of popular protest and then negotiated power-sharing. Why the willingness to give way to public protests?

Publication of Stasi memoranda provided some insight into this issue early on. They suggest that by 1989 many of the leaders of the east European states understood that they had arrived at a dead end in terms of their own aspirations and policies. In part this was a recognition of relative economic failure; in part a generational issue; in part a confrontation with the culture of expressive personal values (call it postmodernity) whose corrosive dissolution of communist public virtues they could not withstand. 
Some accounts, such as Padraic Kenney's, in fact construe the upheavals of I989 as the triumph of a carnivalesque - a transformation scripted by Bakhtin. Carnivalesque exuberance there certainly was - recall Timothy Garton Ash's depiction of the 'Magic Lantern' in Prague. ' Still, in a transformation that required and elicited so many dimensions of psychological and ideological reorientation, it is impossible to establish what role the playful played alongside the serious, or music alongside prose. Indeed, that judgement probably depends on the historian's own enthusiasms; I tend to think that the carnivalesque phenomena constituted more the mood music of transformation rather than its underlying force. Still, popular music may perhaps be inseparable from every great upheaval, for music carries along the promise of a private fulfilment that only new public conditions will allow. 'We'll meet again', and even 'Lily Marlene', helped to make tolerable the mortal separations of the Second World War; 'Hey Jude' in Czech may have helped to keep the velvet revolution velvet.

We historians have perhaps paid too little systematic attention to the dialectic of private and public in I989. For if - as east European intellectuals have often claimed the private seemed more poignant and literature, for instance, more significant in a world of repression (just as religious ceremonies seemed more meaningful when they had to be held in secret or at least as acts of defiance), nonetheless it was the restraints on the 'private' that made the arguments for public transformation so compelling. Private longings and aspirations could be emancipated only by rejecting the ideological straitjacket of a system that really did not want to grant their legitimacy. In that case emancipation had to bring a sense of trivialisation. Akhmatova, Szymborska, Herbert, perhaps Woytyła hardly celebrated the public sphere. Lenin supposedly said that he could not permit himself to read poetry lest his revolutionary commitment falter. Leninism or latter-day communism found it hard to deal with any deep interiority, which represented the seductions of bourgeois culture and would supposedly become otiose in a collective order. In this respect, the aesthetics and metaphysics of the far left differed from those of fascism. For fascist ideology and aesthetics maintained (alongside fascism's indubitable fascination with the hardness of technology) a fascination with death and sacrifice that Leninism never really cultivated, despite the corpses it had found necessary to pile up. For the nomenklatura of 1989 what was taking place was the return of the repressed, not only inexplicable because it had survived so strongly, but demoralising because their own values had apparently taken such shallow root.

Still, the rulers of 1989 faced more than just the irrepressible claims of the private sphere. It was simultaneously a looming failure in the public sphere that they had claimed had to be the site of progress. As Stefan Wolle put it, both by virtue of the Stasi documents he and Armin Mitter published in I990, 'Ich liebe Euch doch alle...', and in his general study of I998, Die heile Welt der Diktatur, many members

7 Padraic Kenney, A Carnival of Revolution: Central Europe 1989 (Princeton, NJ: Princeton University Press, 2002); Timothy Garton Ash, The Magic Lantern: The Revolution of '89 witnessed in Warsaw, Budapest, Berlin, and Prague (New York: Vintage, I993). For 'refolution', see Garton Ash, Uses of Adversity, 309-24. 
of the security apparatus believed that they should be loved, and thus were shocked to find that the benevolence of their mission was so repudiated. ${ }^{8}$ The more insightful communist leaders throughout east-central Europe understood that although they might continue to hold on to power by coercion, they could not manage complex societies which were obviously no longer structured according to the binary principles the leadership had earlier presupposed. How did one maintain a state of workers and peasants, when modern societies required teachers, managers, therapists, travel agents, clothing designers, computer programmers, Olympic coaches, restaurateurs, television programmers, fast food suppliers and the providers of what the state called 'the thousand little things'?

After the Berlin and German treaties were signed at the beginning of the I970s only the most stubborn and hidebound state socialist leaders, or a state security apparatus convinced that it still functioned as 'the sword and shield' of the regime, might still believe that a commonwealth of workers and peasants was menaced by an imperialist conspiracy. So, too, none but the most reactionary military leaders in Latin America or Iberia or, later, none but the most diehard white supremacists in South Africa could remain convinced that they faced a powerful communist conspiracy at home. The authoritarian rulers of the I970s and I980s had already been compelled to make some concessions but still felt threatened by immanent and powerful subversive conspiracies abetted from abroad.

It is worth recalling that not only communist leaders surrendered their power; rightist military regimes moved toward 'opening' in the same era and dismantled their dictatorships. Underlying these abdications, left and right, was the growing division among the authoritarian rulers themselves, as a rising generation of functionaries sensed that they faced a political dead end. Martial law could hardly ensure that workers delivered high-quality labour.

As they contemplated relinquishing their monopoly of power, communist reformers, however, did not realise how totally they would be repudiated. Economic decay and the strength of dissent made persistence in forcible rule costly and unattractive; acceding to reforms would - so it was probably calculated - allow the holders of power to retain the decisive upper hand. They placed their hopes in the reform of the Party cadres; but the history of October I989 to spring I990 shows that they badly underestimated the avalanche they allowed to develop and even the panic that would take hold of the party structures. Whether Gorbachev's belief that a reformed communist party might remain in charge of a reconfigured Soviet Union, or the Polish party's year-long conviction it could dominate the Sejm, or the Krenz and even Modrow government's belief that they might steer a viable GDR state into a new German confederation - those who chose the option of peaceful reform in I989 underestimated the momentum of the currents that would sweep them away.

\footnotetext{
8 Armin Mitter and Stefan Wolle, eds., 'Ich liebe Euch doch alle': Befehle und Lageberichte des MfS JanuarNovember 1989 (Berlin: BasisDuruck, I990); Armin Mitter and Stefan Wolle, Untergang auf Raten: Unbekannte Kapitel aus der DDR Geschichte (Munich: Bertelsmann, I993); Stefan Wolle, Die heile Welt der Diktatur: Herrschaft und Alltag in der DDR (Berlin: Chr. Link Verlag, I998), pp. I26-7.
} 
Martin Malia's celebrated anonymously published article, 'To the Stalin Mausoleum', made the case for the impossibility of this halfway house in Russia, but the argument holds for the other east European states as well. ${ }^{9}$

\section{Herrschaft and Gesellschaft}

More of a continuing challenge than accounting for the downfall has been trying to subsume late communist regimes under an ideal type. Most historians felt uncomfortable with the typologies on offer, and I believe that this still remains the case. No single concept - whether 'late totalitarianism' or 'posttotalitarianism', a 'second German dictatorship' (used by Jürgen Kocka), the 'welfare dictatorship' (Fürsorgediktatur) proposed by Konrad Jarausch, and so on - serves entirely satisfactorily, as Jeannette Madarász has recently suggested in her review of the concepts. ${ }^{10}$ When I used the term 'late communism', in my own account of GDR collapse, I meant really to avoid a generalising model and to restrict description to the unique characteristics of the east European regimes in the I970s and I980s that is, to insist on the temporal dimension of analysis.

The redeployment of a 'totalitarian' model after 1989 rested in part on specific German preoccupation with the role of the Stasi and an effort to render an account for the repression of forty years. But it also formed part of an international reaction already a decade long against what was perceived as a European left that had been too willing to make its peace with communist rule in eastern Europe. French 'nouveaux philosophes' and US neoconservatives exemplified the trend outside Germany. Indeed, it was animated by what found an equivalent outlet in the emerging American neoconservatism of the era. As best represented by historians among the so-called Verbund SED-Staat research group, the model allowed little scope for the autonomy or agency of an East German public. ${ }^{11}$ The German formula often used in these analyses, especially when deployed in West German political-party battles, was Unrechtsstaat, obviously meant to contrast with Rechtsstaat, but a designation so totalising and vague as to be analytically useless. There have been many Unrechtsstaaten in the world, ranging from personal despotisms such as Charles Taylor's in Sierra Leone or more recently Robert Mugabe's in Zimbabwe to military dictatorships such as the Argentine generals imposed. ${ }^{12}$ And even Rechtsstaaten often have enclaves where ordinary law remains suspended as in the US South before the end of segregation or more recently in Guantánamo or Abu Ghraib.

The efforts to describe the workings of society, economy and culture under late socialism have been more satisfactory, I believe, than theories of political power.

9 Martin Malia, 'To the Stalin Mausoleum', Daedalus I I9, I (I990), 295-344; reprinted in Stephen Graubard, ed., Eastern Europe. . Central Europe, Europe...USA (Nashville: Westview Press, I99I).

10 Jeannette Madarász, Conflict and Compromise in East Germany, 1971-1989 (Basingstoke: Palgrave Macmillan, 2003), 5-IO.

11 See Klaus Schroeder and Steffen Alisch, Der SED-Staat: Partei, Staat und Gesellschaft, 1949-1989 (Munich: Carl Hanser Verlag, I998); Mitter and Wolle, Untergang auf Raten.

12 For the broad range of despotisms see Daniel Chirot, Modern Tyrants: The Power and Prevalence of Tyranny in our Age (New York: Free Press), I994. 
Jeffrey Kopstein's discussion of class, Andrew Port's description of how the Party manipulated grievances and concessions in the Saalfeld industrial zone, Corey Ross's study of socialism 'at the grass roots', in Brandenburg, have all conveyed the texture of grumbling, acquiescence, accommodation and unhappiness with the Party's feckless efforts to run an industrial society. On the basis of his intense study of the Ulbricht era in Saalfeld, Port has produced the most textured local study that we have, including the complexities of women's role in the workplace. He has persuasively suggested that precisely the grumbling of differentially privileged groups of workers with respect to each other precluded a unified working-class consciousness and thus helped keep the Socialist Unity Party (SED) in power for so long. ${ }^{13}$ German studies of censorship, book production and cultural self-enforcement by Manfred Jäger, Siegfried Lokatis, Simona Barck and others have conveyed a good sense of the ambiguities of dissent and conformity. As the controversy over Christa Wolf revealed, the texture of negotiation and restrained irony before 1989 would allow for ample controversies and denunciations afterwards. The fine line trodden by the Protestant Churches has stimulated a similarly differentiated description.

In effect, each of these subsystems revealed patterns of surveillance and coercive punishment of those who overstepped narrow bounds but also allowable space for either complaining or negotiating. They could vary as to how autonomous that space might be. Stefan Wolle, who originally produced a rather undifferentiated treatment of GDR totalitarianism, Untergang auf Raten, dashed off when he was a dissident historian exiting from the GDR and angry at some of the softer treatments his former colleagues seemed to offer, produced a far more differentiated study almost a decade later. ${ }^{14}$ Still, Wolle seems to have resolved the tension between regime and society by emphasising the discrepancy between ideological project and social reality. In almost satiric tones he depicts the regime more as feckless than totalitarian and the society as corrupted rather than controlled - an impression created in part through the bleak photographs as well as the text: East Germany as a third-world dictatorship.

If one sought a general social theorist whose models might accommodate this reality, it would probably be the late Niklas Luhmann, who sought to capture the complexities of modern liberal societies, but does not serve us badly in understanding the compartmentalisation inherent in state socialism. Luhmann suggests that to try and discern an overarching model or idea of substantive rationality for a social system as a whole (the implicit target is Jürgen Habermas) remains a misguided search for totality. Instead, society consists of subsystems - economies, communications, politics, even

13 See Jeffrey Kopstein, The Politics of Economic Decline in East Germany, 1945-1989 (Chapel Hill: University of North Carolina Press, I997); Andrew I. Port, Conflict and Stability in the German Democratic Republic (Cambridge: Cambridge University Press, 2007); Corey Ross, Constructing Socialism at the Grass-Roots: The Transformation of East Germany (Basingstoke: Macmillan, 2000).

14 Wolle, Die heile Welt der Diktatur. Wolle had been dismissed from the Humboldt University in I972 and had found a berth at the Academy, but in I989 withdrew to help found the 'Unabhängiger Historikerverband'. Since I had a role in Jürgen Kocka's Center for Contemporary History established in Potsdam by the Max Planck Gesellschaft precisely to 'rescue' some of the young East German historians of the Academy of Sciences whom Wolle condemned as apologists, he seemed a rather annoying gadfly. 
the erotic - which have their specific logics and rules. Ironically enough, Luhmann, the liberal functionalist, provides the better guide to state socialism, while the more totalising concepts of either Habermas or the early Foucault remain more suggestive for liberal or social-democratic aspirations. ${ }^{15}$

Still, separating society from regime, Gesellschaft from Herrschaft, presents its own analytical perils. Overall assessment must differ according to whether one focuses on the regime or the society considered separately from the structures of rule. Significantly, the title of Mary Fulbrook's The People's State: East German Society from Hitler to Honecker takes us seamlessly from state to society, although she intends to keep them separate spheres. ${ }^{16}$ Whereas for Stefan Wolle, 'the society of the GDR was poisoned to its core, ${ }^{17}$ for Fulbrook society remains an autonomous arena that escaped largely unscathed. Fulbrook wishes

to present a coherent overview of the distinctive patterns and development of East German society that manages to do justice both to a wide range of lived experiences and to the underlying structures of which contemporaries may well have been unaware... This book is, thus, about the ways in which most East Germans lived their lives, under changing conditions, over the decades from the collapse of Hitler's Third Reich through to the collapse of the GDR.

It is about the ways in which the GDR was not merely a communist state in a Cold War context, but also a modern industrial society facing familiar economic challenges, participating in wider patterns of globalisation and cultural and social change ... and about the ways in which it is not possible adequately to understand GDR history in the terms of dichotomous notions of regime versus people. ${ }^{18}$

Fulbrook claims to recognise that GDR social history was fundamentally affected by politics; 'it cannot be understood without analysis of political structures and processes'. Others may disagree, but my sense is that her study in fact tends to efface the politicisation of society: 'Faced with accounts of repression, complicity, and collusion, former citizens of the GDR claimed that their own memories and experiences told them otherwise.' Their own biographies 'did not seem to fit easily within the bleak picture of oppression and fear'. 'The SED actually wanted to do something with their power: to transform society into what they thought would be a better, more egalitarian, more just society'. 'GDR history needs to be considered not merely from the perspective of "dictatorship", or "communist state", but also from that of "modern industrial society".' 'Concentration of public debate on the Stasi must not shift the gaze that it was merely one part of the perfected security, disciplinary and surveillance structure. To that belonged the party, the mass organisations, the block parties, the Volkspolizei. ${ }^{\prime 19}$ But these institutions hardly provided the conditions for a vital and autonomous social development!

15 Niklas Luhmann, Social Systems, trans. John Bednarz (Stanford: Stanford University Press, I996).

16 Mary Fulbrook, The People's State: East German Society from Hitler to Honecker (New Haven, CT: Yale University Press, 2005).

17 'Die Gesellschaft der DDR war bis ins Innerste vergiftet.' Wolle, Die heile Welt der Diktatur, I 52-3.

18 Fulbrook, People's State, xii.

19 Ibid., I, 9, I I. 
The view presented takes us to a central problem in the historiography of modern dictatorship. 'Industrial society', which Fulbrook cites as a typology that can allegedly transcend a clichéd view of the German Democratic Republic, served indeed as an ideal type valuably developed by Raymond Aron and Daniel Bell in the I950s and I96os to overcome sterile cold-war confrontational stereotypes. I am not certain that it provides the same analytical utility today. It was a concept we can valuably invoke for the GDR experience through the I960s - as Andrew Port has done. It serves us less well after the VIIIth Party Congress with its so-called 'unity of social and economic policy' - namely the commitment to a consumer society. East Germany collapsed not because it functioned badly as an industrial society, but because it performed lamentably as a post-industrial society, as Mark Landsman and Jonathan Zatlin have both recently demonstrated. ${ }^{20}$

But there is a deeper issue involved. Can one study Gesellschaft without studying Herrschaft under conditions of dictatorship? Indeed, to hark back to Tocqueveille's Democracy in America, one could not study democracy as a regime without understanding the society in which it was immersed. But Tocqueville could presuppose that the authority system reflected the organisation of society. The central claim of theorists of totalitarianism, including pre-eminently Hannah Arendt in her Origins of Totalitarian Democracy, is that it is a regime type powerful enough to disaggregate and atomise society as a tool of rule primarily through the tools of terror.

Of course, this claim has been contested. Recent discussions of Martin Broszat's work on Nazi rule emphasise that his Bavaria project and efforts to 'historicise' National Socialism were an assault on the claim of atomisation. In Broszat's cumulative historical production, the regime clearly possessed uniquely terroristic capacities but individuals in society might still escape relatively unscathed and non-responsible. ${ }^{21}$ As a historian Broszat was wrestling with personal issues of responsibility. Fulbrook faces no such problem. But can people's memories or beliefs that their lives were hardly circumscribed under dictatorship really serve as historical evidence about the nature of the system under which they lived? The problem with everyday history is precisely that most people can go through life without feeling subjectively impinged on by politics if they make no effort to engage politically. But in such powerful state projects, to write a history of society as autonomous - or present a view of society as in Edgar Reitz's skilful television drama series, Heimat - must lead to a partial account of the past.

20 Jonathan R. Zatlin, The Currency of Socialism: Money and Political Culture in East Germany (Washington, DC: German Historical Institute, and Cambridge: Cambridge University Press, 2007); Mark Landsman, Dictatorship and Demand: Consumerism in East Germany (Cambridge, MA: Harvard University Press, 2005).

21 See the recent conference devoted to the work of Martin Broszat edited by Norbert Frei: Martin Broszat, der 'Staat Hitlers' und die Historisierung des Nationalsozialiismus (Weimar: Wallstein, 2007), especially the intervention by Dan Diner, I $8 \mathrm{I}-7$. The critique by Nicholas Berg, 'Struktur ist Intention'.... 
True enough, although the two domains of Herrschaft and Gesellschaft overlapped and powerfully shaped each other; they were not fused. Enough of people's family and personal lives, indeed, enough of their organisational lives remained distinct to merit analysis. This does not mean that they could always protect them. Not all niches, to use Günter Gaus's famous image, were sanctuaries: the coercive state could intrude if it had reason to - which is the truth on which Florian von Donnersmarck has built his film, The Lives of Others. Nonetheless there was enough differentiation that each domain will convey a different total reality. Describe the communist state, and the historian conjures up an image of illiberal surveillance and the manipulation of fear and privilege. Describe the communist society, and one can end up with a trivialisation of coercive mechanisms.

What was essential and ironic was the fact that this state really wanted the participation of this society. The enlistment of society in its project was the test of legitimation. Hence, too, the importance of overwhelming election approval even when there was only a single party. But the state project was not - and here I depart from Fulbrook - a utopian search for an egalitarian society. Rather, it became merely approval and acclamation in its own right. What Clifford Geertz claimed about Negara, the theatre state of Bali that the Dutch conquered in I906, was true in its way of late communism: the spectacle of rule was the objective of rule. The goal was the non-utopian hope to have society constantly affirming the party's tutelary role. The state (or party) needed the society for validation; and society grew used to receiving privileges or penalties - Germans talk about Zuckerbrot oder Prügel, cookies or knout, although under GDR conditions one might say Privileg oder Prïgel - from the state.

That is also why it is plausible to find analogies with the eighteenth-century notion of Polizey. Rolf Heinrich had it right when he pointed to the parental role of the state and the infantile role assigned to society. ${ }^{22}$ Thus making a claim for what the Germans call Mündigkeit (maturity or autonomy, literally the maturity to speak out) had to be subversive or at best negotiated, so that it took place within walls, such as in churches. Thus, too, the particular affinity of the Czech and East German experiences: both took place in societies that had developed under the auspices of ancient-régime Polizey, whether Prussian-Saxon, or Austrian. Both developed patterns of risk-avoidance and ample denunciation - in contrast to the Polish pattern of defiance and suppression, or even the Hungarian experience of connivance with the state and party in evasive behaviour. ${ }^{23}$

Facing the anniversaries of I989, the challenge is (as it always should have been) to write what might be called a 'moral history' - that is, one about choices. A moral history cannot be one just of late communist 'experience', for an experiential

22 Rolf Heinrich, Der vormundschaftliche Staat (Reinbek bei Hamburg: rororo aktuell, I989).

23 For denunciation as a common thread on left and right see Sheila Fitzpatrick and Robert Gellately, eds., Accusatory Practices: Denunciation in Modern European History, 1789-1989 (Chicago: University of Chicago Press, 1997); also Gellately, The Gestapo: Enforcing Racial Policy (New York: Oxford University Press, 1990). Fizpatrick's effort to write the history of society under Stalinism seems a more skilful one, Everyday Stalinism: Ordinary Life in Extraordinary Times: Soviet Russia in the 193os (New York: Oxford University Press, I999), recognizing the impingement of state transformation on social praxes. 
history will tend to document either subjectively perceived autonomy, and implicitly serve apologia, or repeated acts of coercion, menace or privilege. But neither can a moral history just be an account of the regime, for a regime history will find mostly secrecy and surveillance, and grandiose self-description alternating with clientelistic bargains. A Black Book of Communism can supply an indictment, but allows for little discussion of how people might in fact survive terror and coercion. A moral history of late communism must be an account of the continuing negotiation between collective or private action and party control and abuse. Inhabitants of a territory could choose to live private lives and pay the cost of outward obedience, like Havel's greengrocer with the party slogan in his window, or parents who let their children undergo the Jugendweihe. In this case the word 'citizenship' may be inappropriate. Or inhabitants could become sincerely enthusiastic about the conspicuous campaigns of civic mobilisation based on claims of anti-fascism or involving peace demonstrations. Inhabitants could also withdraw into an oppositional silence. Or they could become cynical (Sascha Anderson) or bemused (Guenter De Bruyn). These were all alternatives for negotiation, not of the boundary between private and public, for a firm boundary did not exist, but of a trading zone, a jointly occupied frontier at the spiritual and legal edge of the state. A moral history need not condemn citizens for making one or another of these choices (at least so long as compliance did not injure others), but will illuminate the choices faced and the costs of each.

\section{Communist 'ageing' and the evolution of authoritarian structures}

No matter how the interaction of state and society is described, essential to judging the communist system must be an idea of trajectory or ageing. Most typologies of political systems are efforts to seek an ideal type in which there is no evolutionary component. Communist systems in eastern Europe lasted for almost a half century after they were established in the wake of Soviet armies. They could evolve, but describing that evolution has not been easy. And finding a typology for their later praxis has also proved difficult. They were not really 'post-totalitarian', for the instruments of controlling media and education remained pervasive, although enforced with less violence and harshness than during the early cold war. I have suggested the designation 'late', admittedly a vague term with intuitive (and imperfect) analogues. The ageing process in humans may arrive with a new subjectivity and 'ripeness', but the individual is aware that he shall cease to exist, whereas those who work on behalf of an institution need feel no inevitable end. Historians have studied enough regimes and systems of rule to understand that they can become corrupt: the central power loses control of its offices and its revenues, which are captured by its agents.

Contemplating the state socialist regimes in the I950s, the historian might reflect on the descriptions of 'lateness' that critics have applied to individual artistic trajectories. Historians of Western art at least (I cannot generalise about the treatment of non-Western art) have recognised a characteristic development of styles from initial simplicity to growing elaboration and complexity before they are superseded. 
Theodor Adorno, Edward Said and other theorists have written about 'late style' as a musical or literary phenomenon. Writing about 'late' Beethoven, Adorno denied that the art simply reflected greater subjectivity. He considered such a description to be a psychologising view, which over-simplified what was at stake. Instead subjectivity 'took leave' of the work and emancipated its inherent aesthetic possibilities. ${ }^{24}$

The reader will protest: it makes no sense to press into service an aesthetic concept deployed to illuminate the highest expressions of human creativity and freedom to describe a political system dedicated to crippling liberty and development! Still, it does seem to me that there was a communist late style, whether akin to human ageing with its growing failure to control bodily processes - and with it an awareness of limited time - or with aesthetic strategies. In this case, however, the awareness of ageing did not open up a discovered potential for an artistic and luminous confrontation with finitude. Rather, the political stratagem entailed a recourse to the cynical compromise of earlier ideological commitment. In communist late style, corruption replaced commitment. What Adorno might have termed the possibilities inherent in the work, that is in the system as it had been constructed, were transformed into the accommodation of individualist satisfactions that were earlier supposed to be sublimated into the advancement of the whole. Late communism involved a space for negotiation between regime and the restive citizen after earlier periods of outright coercion established what limits existed - that is, for the post-Stalinist era of east European communism. Its culture allowed for a certain satire, its political interactions permitted a dimension of knowledgeable cynicism on both sides. Youth might still be recruited, but to achieve maturity as an intellectual or an administrator was to become disabused. Any adequate analysis of what was destroyed in I989 must include this dimension of communist late style.

\section{What changed?}

Let us turn in conclusion not to the interpretations of why I989 occurred, or how best to describe the nature of the communist states and societies - but what the end of that experiment signified. I989, a term used as a shorthand, seems indeed to have closed a historical era: the short twentieth century, what Hobsbawm has called the Age of Extremes. Did it close the era of great ideological conflicts, as Fukuyama suggested? Or did the collapse of an ideological alternative that was secular as well as authoritarian allow the remobilisation not just of liberal democracy, but of religion as a force in public life. Or did it in fact signify little? What was perhaps most disappointing is the fact that the communist system did not taint all its placeholders, that many of them seemed to have found, if not positions of leadership, at least jobs in the new system. To a degree this marked the 1945 transition as well: at least in the university and judicial systems, former Nazis and fascists survived quite

24 Theodor W. Adorno, 'Late Style in Beethoven', in his Essays on Music, ed. Richard Leppert, trans. Susan H. Gillespie (Berkeley: University of California Press, 2002), 564-9. Cf. Karen Painter and Thomas Crow, eds., Late Thoughts, Reflections on Artists and Composers at Work (Los Angeles: Getty Research Institute, 2006). 
handily. Perhaps that is the price of institutional renewal. Attributing such heavy blame to 'systems' that were to be transformed made individual responsibilities less of a handicap.

The question remains - even more urgently in 2009 than in 1989 - what exactly was transformed? One can envisage the history of communism in power (and fascism) as a major chapter in a two-century struggle unleashed by economic modernisation and the ideas of the Enlightenment. If this is the case, then the struggle is between two visions of the world. One suggests that fulfilment arises from individual or even familial gain, from the restless effort to win more, understand more and escape from the gravitational weight of tradition and community. Liberty and individual fulfilment are prized, equality and collective achievement seem less important, except perhaps in the realm of games, which always acts as a psychological counterweight to the discipline required by real life. But there is always an alternative to the mobilisation of individual energy and development. And that is the continuing effort to validate collective and not individual fulfilment, to insist that destiny beckons us with a community of belonging and common action, whether achieved through material equality, religious communalism or political authority. Political doctrines can incorporate elements of each approach, although one principle - either the individualist or the collective - tends to prevail over the other. The political left, especially in the nineteenth century, was often associated with the mobilisation of individualism, but it was also about redefining appropriate communities.

Perhaps we learned the wrong lesson from I989. We believed that it constituted a great step forward towards the individualist mobilisation of the species and a decisive defeat for the claims of solidarity, an oppressive solidarity in this case. But suppose another lesson can be read in what has followed I989 - namely that there can be no final victory for the one or the other of these tendencies, that they will always be in conflict, and that if one plausible remedy to give the communal its due proves illusory or deficient or collapses, others will rush into the gap, that, in short, there can be no end to this contention and coexistence of fundamental orientations - and thus no conceivable end to history.

In that case, episodes of emancipatory exuberance must always be followed by efforts to reclaim the communal - by crusades to rediscipline human energies into disciplined orientations. I870 followed I 848 in Europe, I933 followed I9I 8 in Germany, I980 followed I 968 in the United States, and 200 I has followed I 989. I do not say that this is the last perspective we shall have on I989: like a massive mountain that one sees first from a distance with a clear profile, then from close up, then perhaps from the trails along its slopes, where the profile disappears, and finally a receding perspective as we leave it behind, there will be no one view that is correct. None of these subsequent views negates the extraordinary vista that loomed up earlier. We were privileged, if not to participate in, then just to witness I989. But it seems to me that we cannot rest with what we learned then, no matter how promising it appeared. 